\title{
AZ INNOVÁTOROK KÖVETKEZŐ GENERÁCIÓI FELÉ - A K + F STÚDIÓ TEHETSÉGFEJLESZTŐ PROGRAMJA
}

\section{Szerzők:}

Mező Ferenc

Eszterházy Károly Egyetem

Mező Katalin

Debreceni Egyetem

\author{
Lektorok:
}

Koncz István

Professzorok az Európai Magyarországért

Erdei Tímea

Eötvös Loránd Tudományegyetem

Első szerző e-mail címe:

ferenc.mezo1@gmail.com

Mező Ferenc és Mező Katalin (2017): Az innovátorok következő generációi felé - a K+F Stúdió tehetséggondozó programja. Különleges Bánásmód, III. évf., 2017/3. szám, 111-113. DOI 10.18458/KB.2017.3.111

\begin{abstract}
Absztrakt:
E cikk célja, hogy bemutassa a $K+F$ Stúdió tehetségfejlesztö programját. Ebben a programban fiatal diákok és tudósok tervezik és publikálják saját innovációikat, részt vesznek az innovációval kapcsolatos tanfolyamokon, találkozókon és konferenciákon. E programot a $K+F$ Stúdió végzi az NTP-PKTF-17-0017 projekt támogatásával.
\end{abstract}

Kulcsszavak: innováció, tehetség

Diszciplína: pedagógia

\begin{abstract}
TOWARD TO THE NEXT GENERATIONS OF INNOVATORS -THE TALENT DEVELOPMENT PROGRAM OF THE K+F STÚDIÓ

The aim of this article to show on a talent development program of the $K+F$ Studio.

In this program young students and scientists plan and public own innovations, and they take part in courses and meetings and conferences about innovations. This program is realized by $K+F$ Stúdió with support of NTP-PKTF-17-0017 project.
\end{abstract}

Keywords: innovation, talent

Discipline: pedagogy

Az emberi közösségek közötti kulturális, tudományos, technikai és gazdasági versengés jóformán egyidős az emberiséggel. Az innovációk (háborúban és békeidőben egyaránt) az ősközösségekben ugyanolyan fontos szerepet játszhattak, mint az ókori városállamokban, a középkorban vagy az újkori társadalmakban. A hidegháború időszakában, különösen pedig a Szputnyik-1. mühold 1957-es fellövésétől - s az azzal járó úgynevezett Szputnyik-sokktól kezdve a tudományos, technikai innovációk tekintetében különösen felértékelödtek a 
nemzetgazdasági és nemzetvédelmi aspektusok. Ennek sajátos lecsapódása volt például az USA 1958-as oktatási törvénye, melyben nemzetvédelmi jelentőségünek tekintették a szovjet tudománnyal versenyképes amerikai tudós generációk felnevelését.

Természetesen a tágkörü, nemzetközi és nemzeti (makro)szintü innovációs verseny mellett létezik egy mezo-szinten (a cégek, szervezetek között) megnyilvánuló innovációs verseny, $\mathrm{s}$ mikro-szinten, vagyis a kutatók, az innovatív egyének között is megnyilvánulhat az innovációk terén megjelenő versengés. Noha hosszasan lehetne polemizálni arról, hogy hasznos vagy haszontalan-e a nemzetek, szervezetek, egyének közötti versengés, tény azonban, hogy a jelenség létezik, s tény az is, hogy a sikeres innovációk napjainkban is bevételt teremthetnek mind az innovátorok, mind az őket alkalmazó szervezetek, $\mathrm{s}$ mind a nemzetek számra. Azt sem szabad azonban figyelmen kívül hagynunk egy nemzet vagy egy szervezet innovációs potenciáljának egyik legjelentősebb tényezője: az innovatív egyén. Ergo: törekednünk kell innovatív generációk felnevelésére is.

Az újításokra nyitott, innovatív tudós generációk fejlesztése érdekében nemcsak egy-egy szakterületen eddig felhalmozott kulturális ismereteket és módszertani jártasságot szükséges átadni a fiataloknak, hanem egyrészt az innovációk felé pozitív attitüdöt, másrészt módszertani jártasságot is formálni kell. Mindez a köznevelés szintjén elsősorban általános jellegü kreativitásfejlesztést jelent, de a felsőoktatásban már konkrét innovációs feladatokba és projektekbe történő bevonásra van szükség.

A K+F Stúdió Kft. (www.kpluszf.com) e feladatra vállalkozott „Innovátor Kör” címü tehetséggondozó programja megvalósítása során. A program az Emberi Erőforrások Minisztériuma (mint támogató), Emberi Erőforrás Támogatáskezelő (mint lebonyolító) és a Nemzeti Tehetség Program által meghirdetett „A hazai és határon túli pályakezdö, kiemelkedöen tehetséges fiatalok példaértékü innovációinak és társadalmi felelösségvállalásuk erősitésének támogatása" kiírás egyik támogatott pályázata lett (pályázati azonosító: NTP-PKTF-17-0017).

A program föbb tartalmi pontjai:

- A fö program egy 30 órás „Innovátor Kör” címü foglalkozássorozat. Ez olyan témaköröket érint, mint: innovációs esetfeldolgozás és az innovációs folyamat modellezése, önismereti tréning az ön-menedzselés jegyében, az innovációs környezet sajátosságai és résztvevői, kreatív kapcsolatalakítási stratégiák - határon innen és túl, kreatívitásfejlesztő tréning, vezetői készségfejlesztő tréning, kommunikációs és konfliktuskezelési tréning, innováció és társadalmi felelösségvállalás, innováció és jogvédelem.

- „Innováció és vállalkozás létrehozás, fejlesztés” című workshop, ami alkalmával mühelymunka keretében az egyéni és a társas vállalkozások létrehozásának és müködtetésének modellezésére kerül sor. A workshop kapcsolódása a főprogramhoz: a mühely keretében az innovációk szervezeti hátterét nyújtó szervezeti lehetőségekről szóló hasznos ismereteket szereznek a résztvevők.

- Poszterkiállítás a bevont fiatalok innovációs terveit tartalmazó müvekből 2018. májusában a III. Nemzetközi Interdiszciplináris Konferencián. A kiállítás révén egyrészt nyilvánosság biztosítható, másrészt a (poszter tervezésétől a poszterrel kapcsolatos szóbeli prezentáció előadásán át a vitáig terjedő) kommunikációs készségeket valós helyzetben gyakorolhatják a résztvevők. Ezen túlmenően igazolt prezentációs teljesítményt nyújtanak a résztvevők, és talán szakmai érdeklődőkre, befektetőkre is lelhetnek a fiatalok.

- A résztvevők számára külföldi szakértő által tartott tréning is rendelkezésre áll, ami alkalmával a föprogramban tanultakat egy fiktív innovációs folyamat végig vezetése során is gyakorolhatják.

- Mindezek mellett az Innovátor Kör tagjai esetében az ön-menedzselő készségek, az önismeret, a kreativitást segítő módszerek, a vezetői készségek és a társadalmi felelősségvállalás témakörei kitüntetett figyelmet kapnak. 
Az Innovátor Kör konkrét eredményeként a résztvevők innovációs tapasztalataikban gazdagodnak, portfóliót készítenek egy általuk kiválasztott innovációval kapcsolatban, e portfóliókból ISBN számmal is ellátott internetes gyüjteményes kötet kerül közreadásra, illetve kisfilm készül a projektről. 